\title{
V.V. Prokopiv ${ }^{1}$, I.V. Horichok ${ }^{1}$, T.O. Semko ${ }^{1}$, R.O. Dzumedzey ${ }^{1}$, G.D. Mateik ${ }^{2}$, O.I. Khshanovska ${ }^{1}$ \\ Thermodynamic Analysis of the Defective Subsystem of Lead Telluride Crystals with Impurity of Oxygen
}

\author{
${ }^{I}$ Vasyl Stefanyk Precarpathian National University, 57, Shevchenko Str., Ivano-Frankivsk, 76018, Ukraine, \\ e-mail:fcss@pu.if.ua \\ ${ }^{2}$ Ivano-Frankivsk National Technical University of Oil and Gas, 15, Karpatska Str., Ivano-Frankivsk, 76000, Ukraine.
}

\begin{abstract}
Electrophysical properties (specific conductivity, Seebeck coefficient, Hall effect) of the lead telluride obtained by pressing of the powder were investigated. In this case, the powder was pre-heat treated at $300 \mathrm{oC}$ in the air to saturate it with oxygen. To interpret the experimental data obtained, a model of a defect subsystem of crystals of lead telluride with impurity of oxygen is proposed.
\end{abstract}

Keywords: Lead telluride, doping, pressing, Seebeck coefficient

Article acted received 11.02.2019; accepted for publication 15.032.2019.

\section{Introduction}

Lead telluride is a semiconductor material of the group A4B6, which is used to create thermoelectric energy converters [1-3]. Particularly effective are the materials obtained by pressing the powder, which, on the one hand, allows to independently control the electronic and phonon subsystem independently and, on the other hand, to create samples of the required size and shape. In addition, pressed materials based on $\mathrm{PbTe}$ are characterized by better mechanical properties compared to monocrystalline [4-6].

When using the powder compression method for obtaining thermoelectric materials, the amount of technological operations grows required to obtain a thermoelement for research or practical use. Despite the fact that predominantly all these procedures are carried out in the protective atmosphere of inert gas, it is difficult to completely avoid the interaction of the material with atmospheric oxygen. Therefore, the study of the influence of oxygen on the properties of PbTe is an urgent task.

Studies [7-8] show that the diffusion of oxygen in $\mathrm{PbTe}$ can lead to the appearance of near-surface regions of p-type conductivity with a carrier concentration of $\approx$ $10^{18} \mathrm{~cm}^{-3}$. The thickness of this layer will depend on the time of exposure, the temperature and may be tens of micrometers, which is proportional to the size of the $\mathrm{PbTe}$ grains used to press the thermoelements. The task of this work was to obtain samples by pressing from annealed powder in the air, to measure the concentration of carriers in them and to offer a model of a defective subsystem for the interpretation of the data.

\section{Experiment}

Synthesis of investigated semiconductor materials was carried out by fusion of components in vacuumed ampoules of the quartz glass brand of Pirex. Ampoules were made of tubes with an outer diameter of $20 \mathrm{~mm}$ and a wall thickness of $2 \mathrm{~mm}$. Before loading, the ampules were cleaned with a mixture of nitric and hydrochloric acid. For synthesis, AlfaAesar productions of purity of 99.999\% were used. The pumping was carried out to a pressure of $10^{-4} \mathrm{~Pa}$ using a vacuum post HiCubeEco.

Vacuumed ampoule with materials was placed horizontally in muffle furnace Naberzem, which allowed carrying out all heating-cooling procedures automatically. The synthesis was carried out in several stages: heating to $500{ }^{\circ} \mathrm{C}$ and shutter speed 1 hour, heating to $700{ }^{\circ} \mathrm{C}$, and endurance of 3 hours, heating to $1020^{\circ} \mathrm{C}$ and shutter speed 1 hour, cooling to $900{ }^{\circ} \mathrm{C}$ and extraction from the furnace.

Samples for measuring electrophysical parameters were obtained by pressing the powder obtained by grinding synthesized ingots in an agate mortar. Annealing of powders in the air was carried out in a vessel made of quartz glass. For pressing samples used fractions of size (50-500) microns.

The compression pressure of the samples was $1.5 \mathrm{GPa}$. The diameter of the pressed samples was 5 or $8 \mathrm{~mm}$ (depending on the required measurements), and the height to diameter ratio was $\approx 1: 1$. The obtained samples were annealing in argon at a temperature of $500{ }^{\circ} \mathrm{C}$. 


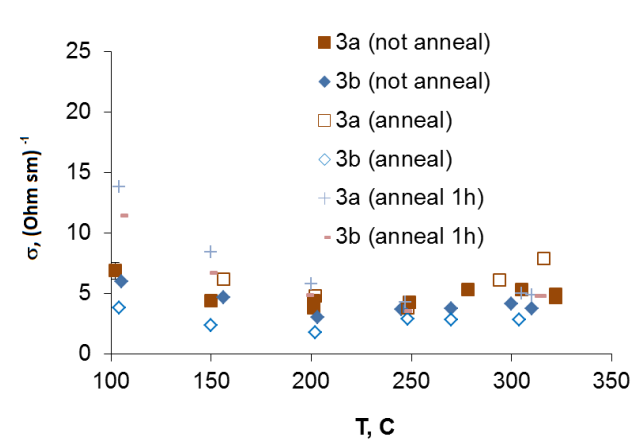

a)

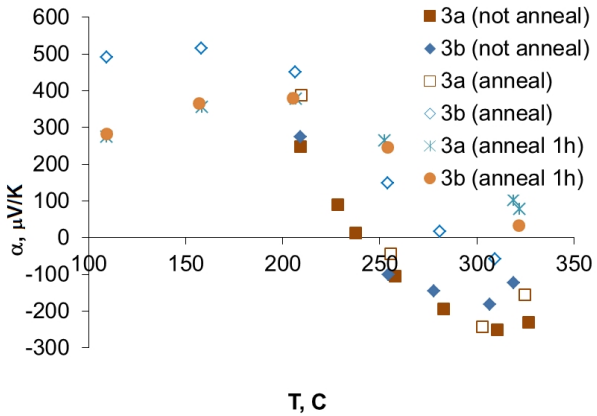

b)

Fig. 1. Temperature dependences of specific electrical conductivity $\sigma$ (a) and Seebeck coefficient $\alpha$ (b) for samples of pressed powder annealed in air at $350{ }^{\circ} \mathrm{C} 2$ hours. Pressure of pressing $1.5 \mathrm{GPa}$ ('not anneal' - not anneal samples, 'anneal' - samples annealed at $500{ }^{\circ} \mathrm{C} 15$ minutes, 'anneal 1h' - samples annealed at $500{ }^{\circ} \mathrm{C} 1$ hour).

The method for measuring electrophysical parameters and the Hall effect is described in detail in [9].

\section{Experiment results and their analysis}

Samples were obtained by pressing a powder that was annealed in the air at $200{ }^{\circ} \mathrm{C}$ for 5 hours shows excellent properties, which may be evidence of the incompleteness of diffusion processes at such annealing temperature and time. An increase in the annealing temperature of the powder to $350{ }^{\circ} \mathrm{C}$ ( 2 hours, also during the heating and cooling of the powder in the furnace) greatly reduces its specific electrical conductivity without changing the quality dependence of $\sigma$ (T) compared to pressed samples of $\mathrm{PbTe}$ witch obtained from no annealing powder [7]. At the same time, the Seebeck coefficient has almost not changed (in comparison with the sample from annealing powder) (Fig. 1).

After the annealing of two equally prepared samples for 15 minutes at a temperature of $500{ }^{\circ} \mathrm{C}$, their conductivity and Seebeck coefficient differed slightly. After annealing during 1 hour, differences were absent. It is important that the concentration of carriers in the samples was the same even after annealing of 15 minutes.

On the Fig. 2. shown that the annealing of the powder does not change the concentration of carriers in the sample, unless the sample itself is annealed. Its temperature dependence is quantitatively and qualitatively similar to those obtained from non-annealed powder [7]. However, after the annealing of the sample itself, the temperature dependence of the carrier concentration is similar to the annealed sample from the no annealing powder, but the numerical values of $n_{H}$ are higher. Such an increase in the Hall concentration, and practically the same for two temperatures of annealing of the powder, may indicate an increase of defects subsystem due to the interaction with oxygen.

X-ray diffraction of oxide phases on annealed powders was not detected, and the cell parameter after annealing slightly decreased: for non-annealed powder PbTe-6.45866 (14) $\AA$, and for annealed in air at $350{ }^{\circ} \mathrm{C}$ (3 hour) - 6.45815 (15) $\AA$. Consequently, the annealing of powders for pressing in the air, on the one hand, leads to a decrease in their specific electrical conductivity, and on the other, to increase the concentration of carriers in them. Reducing the conductivity of the samples seems logical and is caused, most likely, by a decrease in mobility, due to potential barriers at the boundaries of crystallites. The increase of carriers concentration can be interpreted as part of the model of the defective subsystem of PbTe:O crystals.

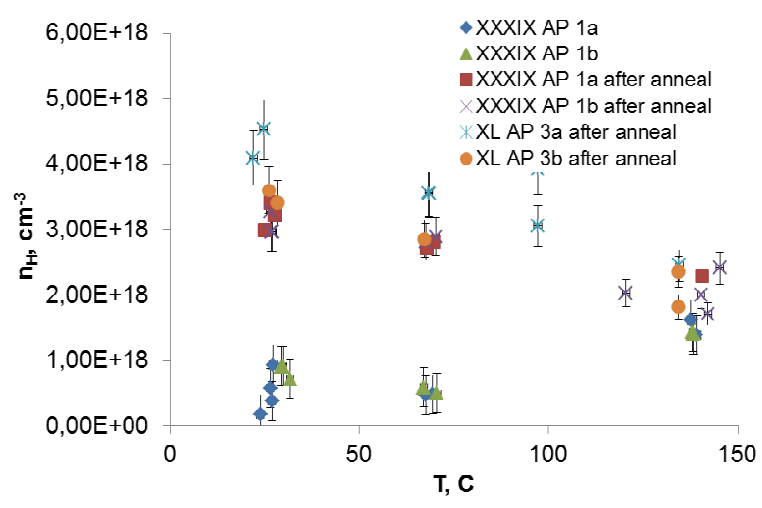

Fig. 2. Dependence of the Hall concentration of carriers on temperature for samples pressed powder annealed in air at $200{ }^{\circ} \mathrm{C} 5$ hours (samples XXXIX AP: '1a', '1b' - samples not anneal, '1a after anneal', '1b after anneal' - samples annealed at $500{ }^{\circ} \mathrm{C} 15$ minutes) and $350{ }^{\circ} \mathrm{C} 3$ hours (samples XL AP: ' $3 \mathrm{a}$ after anneal', '3b after anneal' - samples annealed at $500{ }^{\circ} \mathrm{C} 15$ minutes). Pressure of pressing 1.5 GPa. 


\section{Thermodynamics of point defects lead telluride doped by oxygen}

The concentration of point defects in a p-type conductivity crystal at a given temperature $\mathrm{T}$ can be determined from the condition of the minimum free energy of the crystal [10]:

$$
\begin{aligned}
& \mathrm{F}=\mathrm{F}_{0}+\left(\mathrm{E}_{\mathrm{O}_{\mathrm{Te}}^{0}}+\mathrm{F}_{\mathrm{vib}, \mathrm{O}_{\mathrm{Te}}^{0}}\right)\left[\mathrm{O}_{\mathrm{Te}}^{0}\right]+\left(\mathrm{E}_{\mathrm{O}_{\mathrm{i}}^{-}}+\mathrm{F}_{\mathrm{vib}, \mathrm{O}_{\mathrm{i}}^{-}}\right)\left[\mathrm{O}_{\mathrm{i}}^{-}\right]+ \\
& +\left(\mathrm{E}_{\mathrm{V}_{\mathrm{Pb}}^{2-}}+\mathrm{F}_{\mathrm{vib}, \mathrm{V}_{\mathrm{Pb}}^{2-}}\right)\left[\mathrm{V}_{\mathrm{Pb}}^{2-}\right]-\mathrm{TS}_{\mathrm{k}}-\mu \mathrm{p}
\end{aligned}
$$

where $\mathrm{F}_{0}$ is free energy independent of the presence of defects, $E$ is the energy of the defect formation, $F_{v i b}$ is the free oscillatory energy of the defect, [D] is the concentration of the defect $\mathrm{D}, \mathrm{p}$ is the hole concentration, $S_{k}$ is the configuration entropy, $\mu$ is the chemical potential.

Literary data on the energy of formation of substitutional defects of $\mathrm{O}_{\mathrm{Te}}$ are absent. The formula used for their evaluation was:

$$
\mathrm{E}\left(\mathrm{O}_{\mathrm{Te}}\right)=6\left(\mathrm{E}_{\mathrm{Z}}^{\mathrm{PbTe}}-\mathrm{E}_{\mathrm{Z}}^{\mathrm{PbO}}\right),
$$

where $\mathrm{E}_{\mathrm{Z}}^{\mathrm{PbTe}}$ and $\mathrm{E}_{\mathrm{Z}}^{\mathrm{PbO}}$ are the energy of one bond in the lead telluride and the lead oxygen. The number in front of the brackets is the number of bonds that form an atom in the structure of $\mathrm{NaCl}$ with its closest neighbors. Using data [11], the energy of formation of defects of replacement $\mathrm{O}_{\mathrm{Te}} \mathrm{E}\left(\mathrm{O}_{\mathrm{Te}}\right)=4,84-5,02=-0,18(\mathrm{eB})$

Free oscillating energy of the substitutional defect [10]

$$
\mathrm{F}_{\mathrm{vib}}=\mathrm{x} \cdot 3 \mathrm{kT} \ln \left(\frac{\omega}{\omega_{0}}\right),
$$

where $\mathrm{x}$ is the number of atoms that have changed the frequency of their own oscillations from $\omega_{0}$ to $\omega$. The change in the frequency of oscillations of atoms in the vicinity of the defect of substitution $\mathrm{O}_{\mathrm{Te}}$ was determined by the formula [12]:

$$
\frac{\omega}{\omega_{0}}=\frac{\mathrm{T}_{\mathrm{O}} \theta_{\mathrm{PbTe}}}{\mathrm{T}_{\mathrm{PbTe}} \theta_{\mathrm{O}}}=\frac{54.5 \cdot 125}{1190 \cdot 155} \approx 0.04
$$

here $\mathrm{T}_{\mathrm{O}}, \mathrm{T}_{\mathrm{PbTe}}$ is the melting point, $\theta_{\mathrm{O}}, \theta \mathrm{P}_{\mathrm{bTe}}$ is the Debye temperature for oxygen crystals and lead telluride. Given that $\omega_{0} / \omega<<1$, then $F_{\text {vib }}$ is a negative value, so consequently, the formation of such defects is an energyefficient for crystal (at $\mathrm{T}=1000 \mathrm{~K}, \mathrm{~F}_{\mathrm{vib}} \approx-5 \mathrm{eV}$ ).

For an internodes oxygen atom, it is difficult to perform a similar estimation of the generation energy of a defect, so this value, and also $\omega / \omega 0$, were considered as variation parameters. It should be noted that in order to determine the free vibration energy of the internodes atom in formula (3) on the right of the sign of equality, we must take into account the summand $3 \mathrm{kT} \ln \left(\frac{\mathrm{T}_{\theta}}{\mathrm{T}}\right)-\mathrm{kT}$ [10], where $\mathrm{T}_{\theta}$ is the Debye temperature for PbTe.

Minimization of the function (1) must be made taking into account the condition

$$
\left[\mathrm{O}_{\mathrm{Te}}^{0}\right]+\left[\mathrm{O}_{\mathrm{i}}^{-}\right]=\mathrm{O}_{\text {tot }}
$$

The configurational entropy of the crystal, in the presence of defects in cationic and anionic sublattices, as well as in internodes cavities, will be determined as:

$$
\mathrm{S}_{\mathrm{k}}=\mathrm{S}_{\mathrm{k}, \mathrm{c}}+\mathrm{S}_{\mathrm{k}, \mathrm{a}}+\mathrm{S}_{\mathrm{k}, \mathrm{i}}
$$

where;

$\mathrm{S}_{\mathrm{k}, \mathrm{c}}=\mathrm{k} \ln \left(\mathrm{N}_{\mathrm{c}} \ln \mathrm{N}_{\mathrm{c}}-\left[\mathrm{V}_{\mathrm{Pb}}^{-2}\right] \ln \left[\mathrm{V}_{\mathrm{Pb}}^{-2}\right]-\left(\mathrm{N}_{\mathrm{c}}-\left[\mathrm{V}_{\mathrm{Pb}}^{-2}\right]\right) \ln \left(\mathrm{N}_{\mathrm{c}}-\left[\mathrm{V}_{\mathrm{Pb}}^{-2}\right]\right)\right)$

$\mathrm{S}_{\mathrm{k}, \mathrm{a}}=\mathrm{k} \ln \left(\mathrm{N}_{\mathrm{a}} \ln \mathrm{N}_{\mathrm{a}}-\left[\mathrm{O}_{\mathrm{Te}}^{0}\right] \ln \left[\mathrm{O}_{\mathrm{Te}}^{0}\right]-\left(\mathrm{N}_{\mathrm{a}}-\left[\mathrm{O}_{\mathrm{Te}}^{0}\right]\right) \ln \left(\mathrm{N}_{\mathrm{a}}-\left[\mathrm{O}_{\mathrm{Te}}^{0}\right]\right)\right)$

$\mathrm{S}_{\mathrm{k}, \mathrm{i}}=\mathrm{k} \ln \left(\mathrm{N}_{\mathrm{i}} \ln \mathrm{N}_{\mathrm{i}}-\left[\mathrm{O}_{\mathrm{i}}^{-2}\right] \ln \left[\mathrm{O}_{\mathrm{i}}^{-2}\right]-\left(\mathrm{N}_{\mathrm{a}}-\left[\mathrm{O}_{\mathrm{i}}^{-2}\right]\right) \ln \left(\mathrm{N}_{\mathrm{a}}-\left[\mathrm{O}_{\mathrm{i}}^{-2}\right]\right)\right)$

The chemical potential of free charge carriers can be determined from the equation of electroneutrality, represented as:

$$
-2\left[\mathrm{~V}_{\mathrm{Pb}}^{-2}\right]-2\left[\mathrm{O}_{\mathrm{i}}^{-2}\right]=-\mathrm{N}_{\mathrm{h}} \mathrm{ae}^{-\mathrm{b} \frac{\mathrm{E}_{\mathrm{g}}+\mu}{\mathrm{kT}}}
$$

whereof

$$
\mu=-\mathrm{E}_{\mathrm{g}}-\mathrm{k} \ln \frac{2\left[\mathrm{~V}_{\mathrm{Pb}}^{-2}\right]+2\left[\mathrm{O}_{\mathrm{i}}^{-2}\right]}{\mathrm{N}_{\mathrm{h}}}
$$

then

$$
\mu \mathrm{p}=\left(-\mathrm{E}_{\mathrm{g}}-\mathrm{kT} \ln \frac{2\left[\mathrm{~V}_{\mathrm{Pb}}^{-2}\right]+2\left[\mathrm{O}_{\mathrm{i}}^{-2}\right]}{\mathrm{N}_{\mathrm{h}}}\right)\left(2\left[\mathrm{~V}_{\mathrm{Pb}}^{-2}\right]+2\left[\mathrm{O}_{\mathrm{i}}^{-2}\right]\right)
$$

For a procedure for minimizing free energy, we must find derivatives of (1) for each of the defects, equate them to zero and solve the resulting system of equations. The final expressions for calculating the concentrations of point defects have the form:

$$
\begin{gathered}
{\left[\mathrm{O}_{\mathrm{Te}}^{0}\right]=\mathrm{N}_{\mathrm{a}} \exp \left(-\frac{\mathrm{E}_{\mathrm{O}_{\mathrm{Te}}^{0}}+\mathrm{F}_{\mathrm{vib}, \mathrm{O}_{\mathrm{Te}}^{0}}}{\mathrm{kT}}\right) .} \\
\left(\left[\mathrm{V}_{\mathrm{Pb}}^{-2}\right]\right)\left(2\left[\mathrm{~V}_{\mathrm{Pb}}^{-2}\right]+2\left[\mathrm{O}_{\mathrm{i}}^{-2}\right]\right)^{2}= \\
=\mathrm{N}_{\mathrm{c}} \mathrm{N}_{\mathrm{h}}^{2} \exp \left(-\frac{\mathrm{E}_{\mathrm{v}_{\mathrm{Pb}}^{-2}}+\mathrm{F}_{\mathrm{vib}, \mathrm{v}_{\mathrm{Pb}}^{-2}}-2 \mathrm{kT}-2 \mathrm{E}_{\mathrm{g}}}{\mathrm{kT}}\right) . \\
{\left[\mathrm{O}_{\mathrm{i}}^{-}\right]=\mathrm{O}_{\mathrm{tot}}-\left[\mathrm{O}_{\mathrm{Te}}^{0}\right]}
\end{gathered}
$$

Thus, from equation (7) we obtain the concentration of oxygen atoms in the nodes of telluride; knowing it, as well as $\mathrm{O}_{\text {tot }}$, from equation (8) determines the concentration of internodes oxygen atoms; under the well-known [Oi] from (8), we determine the concentration of vacancies of the lead. Equations (8), solved numerically, in the medium of MAPLE 14. With three possible roots - one real (physical) and two complex conjugate. The thermodynamic parameters of the vacancy in lead are defined in [13].

Figure 3 shows the results of calculating the dependence of the concentrations of point defects and holes on the temperature for PbTe:O. Experimental points are the measurement data for the sample XXXIX 1b obtained by pressing the powder, which was annealed in the air. The value of $\mathrm{O}_{\text {tot }}$ varied to achieve the best agreement of the calculated curve with the experimental data $\mathrm{p}(\mathrm{T})$. The resulting optimum value is Otot $=1.610^{18} \mathrm{~cm}^{-3}$.

The concentration of lead vacancy in the figure is not given, since these numerical values were at the level of $10^{12} \mathrm{~cm}^{-3}$. Consequently, the dominant point defect, which determines the temperature dependence of the measured Hall concentration in the temperature range $\left(30-150{ }^{\circ} \mathrm{C}\right)$, is the internodes oxygen atoms. As the temperature rises, their concentration is decreases, and the concentration of $\mathrm{O}_{\mathrm{Te}}$ substitution defects increases. At 
Table 1

Parameters of elements [11] and calculated deformation contributions into the energy of formation of complexes

\begin{tabular}{|c|c|c|c|c|}
\hline Element & $\mathrm{x}, \Gamma \mathrm{a}^{-1}$ & $\mathrm{r}_{\text {cov }}, \mathrm{A}$ & $\mathrm{r}_{\text {ion }}(2-), \mathrm{A}$ & $\Delta \mathrm{E}^{*}, \mathrm{eB}^{*} 0.26$ \\
\hline $\mathrm{Pb}$ & 0.025 & 1.47 & $1.12(2+)$ & 0.26 \\
$\mathrm{ye}$ & 0.048 & 1.40 & $1.92(2-)$ & 0.55 \\
\hline $\mathrm{O}$ & 0.455 & 0.73 & $1.16(2-)$ & \\
\hline
\end{tabular}

* - the two values correspond to the calculation using covalent and ion (2) radii, respectively.

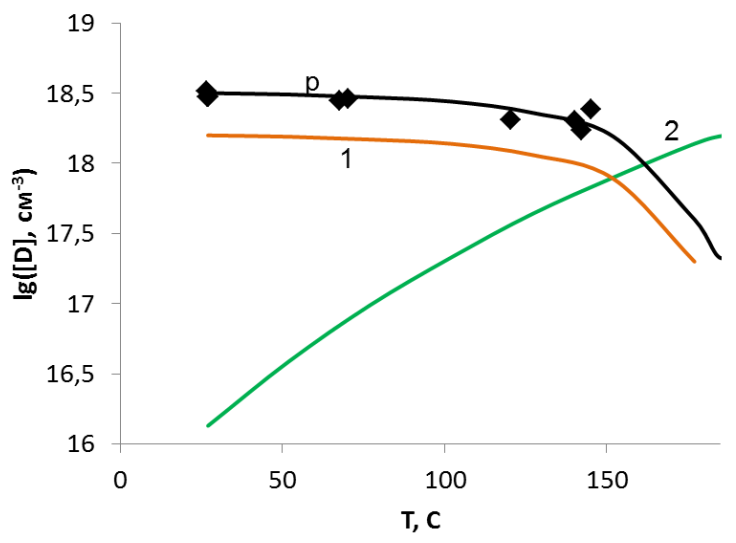

Fig 3. Dependence of the concentration of holes $p$ and point defects $\left(1-\mathrm{O}_{\mathrm{i}}^{-2}, 2-\mathrm{O}_{\mathrm{Te}}^{0}\right)$ on the temperature in the crystals of lead telluride doped by oxygen $\left(\mathrm{O}_{\mathrm{tot}}=1.610^{18} \mathrm{~cm}^{-3}\right)$.

a temperature of $150{ }^{\circ} \mathrm{C}$, the concentration of the latter starts to dominate over the concentration of interstitial atoms. However, in the given temperature range, for the more correct determination of the type of the dominant defect and its concentration, one should take into account the active generation of own charge carriers.

On the basis of the calculated dependences we can assume that the diffusion of oxygen atoms deep into the near-surface layer is carried out by internodes positions where the thermodynamic equilibrium defects are localized. Despite the much lower energy of formation, $\mathrm{O}_{\mathrm{Te}}$ substitution defects cannot be formed at a given temperature, since this requires the release of the telluride atom from its node, and the energy of this process is about $3 \mathrm{eV}$ [13], that is, it is quite high. This conclusion, in particular, is confirmed by the low concentration of vacancies in the lead, for which the formation energy is also $\approx 3 \mathrm{eV}$ [13]. With increasing temperature, the probability of leaving the atom of telluride from its node increases, which contributes to the concentration growth of the replacement defects $\mathrm{O}_{\mathrm{Te}}$, the existence of which, according to the above calculations, is energetically more advantageous for the crystal.

However, this model cannot explain the decrease of the cell parameter for the samples obtained from the annealing powder in the air. The difference in the radii of oxygen and telluride creates preconditions for the emergence of vacancies in the nearest node to the substitution atom, that is, the formation of a defective $\mathrm{O}_{\mathrm{Te}}-\mathrm{V}_{\mathrm{Pb}}$ complex. Its existence could explain the observed changes in the magnitude a.

The energy of the formation of the "impurity atom lead vacancy" complex can be determined by the theory proposed in [14]. The rooting of the impurity into the lattice node causes the occurrence of local deformations around the defect due to the inequality of the radii of the main atom and the substitution atom. These deformations change the energy of the formation of a vacancy in the vicinity of the defect, and this change can be quantified by the formula [14]:

$$
\Delta \mathrm{E} \approx \frac{6 \pi\left(\mathrm{r}_{\mathrm{Te}}-\mathrm{r}_{\mathrm{O}}\right)^{2} \mathrm{r}_{\mathrm{O}}}{\mathrm{z}(1-\alpha) \mathrm{x}_{\mathrm{Te}}}, \alpha=\frac{(1+\eta) \mathrm{x}_{\mathrm{Te}} \mathrm{r}_{\mathrm{O}}}{2(1-\eta) \mathrm{x}_{\mathrm{O}} \mathrm{r}_{\mathrm{Te}}}
$$

$\mathrm{r}_{\mathrm{Te}}, \mathrm{r}_{\mathrm{O}}$ are covalent radii of the impurity atom and the substituted atom, $\mathrm{x}_{\mathrm{O}}$ and $\mathrm{x}_{\mathrm{Te}}$ are the compressibility of the impurity atom and the substituted atom, $\eta$ is the Poisson's ratio of the main substance $\left(\eta_{\mathrm{PbTe}}=0.67\right.$ [15]).

If defects that form a complex ionized, then it is necessary to take into account the electrostatic energy of their interaction:

$$
\Delta \mathrm{E}_{\mathrm{K}}=\frac{\mathrm{z}_{\mathrm{V}_{\mathrm{Te}}} \mathrm{z}_{\mathrm{Ln} \mathrm{Pb}} \cdot \mathrm{e}^{2}}{4 \pi \varepsilon \varepsilon_{0} \mathrm{r}},
$$

where $z_{i}$ - charges of defects, $r$ - the distance between them. However, the oxygen in the tellurium node is most likely in an electroneutral state, so this part is not relevant.

On the other hand, in the case of a purely ionic coupling model relative to the crystalline lattice, oxygen in anionic sublattice should have a charge of -2 , and therefore, electrostatic repulsion may occur between this atom and the twice-negatively ionized lead vacancy. But, given the high static dielectric permittivity $\varepsilon(\mathrm{PbTe})=400$ [16] (and the static dielectric constant [14] must be used for the calculation) $\Delta \mathrm{E}_{\mathrm{K}}=0.02 \mathrm{eV}$, which practically will not affect the result of the calculation. The distance between defects was taken equal to the interatomic distance in the ideal crystal PbTe $(\mathrm{r}(\mathrm{VPb}-\mathrm{OTe}) \approx 3.23 \AA)$.

According to the calculation (Table 1), the formation energy of the complex (that is, the energy gain in its formation) is $0.26 \mathrm{eV}$ when used for calculating the covalent radius, or $0.55 \mathrm{eV}$ using an ion's radius. Such values of formation energies of complexes indicate that their concentrations can be high. 


\section{Conclusions}

1. With the annealing of PbTe powder in air at a temperature of $300{ }^{\circ} \mathrm{C}$, the oxygen atoms actively interact with it, diffusing inward and increasing the concentration of holes. This process is characterized by outlet to the saturation during specific technological annealing parameters, and the maximum observed concentration of carriers of is (4.0-5.0) $10^{18} \mathrm{~cm}^{-3}$.

2. Experimentally measured temperature dependences of carrier concentrations can be explained within the framework of a model that takes into account the localization of oxygen atoms in internodes positions or in anionic nodes. In this case, the weak temperature dependence $\mathrm{n}_{\mathrm{H}}(\mathrm{T})$ may be due to a change in the dominant mechanism of the occurrence of oxygen atoms with temperature change.

3. For a deeper analysis of the defective subsystem of PbTe:O crystals, it is necessary to make calculations using a model that takes into account the formation of the defective $\mathrm{V}_{\mathrm{Pb}}-\mathrm{O}_{\mathrm{Te}}$ complex, the calculation of the energy of which gives rise to the assumption that the concentration of these defects may be commensurate with the concentrations of other dominant point defects.

The work was carried out in the framework of implementation of projects under the state orders of the Ministry of Education and Science of Ukraine, state registration numbers 0117 U006425 and 0119 U100062.

Prokopiv V.V. - Professor, candidate of physical and mathematical sciences, head of the department of physics and chemistry of a solid body;

Horichok I.V. - candidate of chemical sciences, senior researcher;

Semko T.O. - candidate of physical and mathematical sciences;

Dzumedzey R.O. - Researcher;

Mateik G.D. - candidate of physical and mathematical sciences, associate professor;

Khshanovska O.I. - master's degree.

[1] L.I. Anatychuk Termojelementy i termojelektricheskie ustrojstva: Spravochnik (Naukova dumka, Kyiv, 1979).

[2] A.O. Epremjan, V.M. Arutjunjan, A.I. Vaganjan, International scientific journal for alternative energy and ecology, 5 (25), 7 (2005).

[3] A.V Dmitriev, I.P. Zvjagin, UFN, 180 (8), 821 (2010) (DOI: 10.3367/UFNr.0180.201008b.0821).

[4] E. P. Sabo, Termojelektrichestvo, (3), 30 (2000).

[5] A.V. Kuznyeczov, S.D. Letyuchenko, V.V. Moczkin, Termoelektryka, (2), 43 (2002).

[6] Li-Dong Zhao, Vinayak P. Dravid, and Mercouri G. Kanatzidis, Energy Environ. Sci., 7, 251-268, (2014).

[7] I.V. Horichok, V.V. Prokopiv, R.I. Zapukhlyak, O.M. Matkivskyj, T.O. Semko, I.O. Savelikhina, T.O. Parashchuk, Journal of Nano- and Electronic Physics, 10(5), 05006 (2018) (DOI: 10.21272/jnep.10(5).05006).

[8] I.V. Horichok, M.O. Galushchak, T.O. Semko, O.M. Matkivskiy, R.O. Dzumedzey, Physics and Chemistry of Solid State, 19(2), 317 (2018) (DOI: 10.15330/pcss.19.2.147-150).

[9] I. V. Horichok, I. M. Lischynskyy, S. I. Mudryy, A. S. Oberemok, T. O. Semko, I. M. Hatsevych, O.M. Matkivskyy, G. D. Mateyik, R. O. Dzumedzey, SEMST, 14 (3), 53 (2017) (DOI: 10.18524/18157459.2017.3.105564).

[10] I.V. Horichok Termodynamika i krystalokhimiia tochkovykh defektiv u bezdomishkovykh ta lehovanykh halohenamy $(\mathrm{Cl}, \mathrm{Br}, \mathrm{I})$ krystalakh kadmii telurydu. Dysertatsiia na zdobuttia naukovoho stupenia kandydata khimichnykh nauk za spetsialnistiu 02.00.21 - khimiia tverdoho tila. Prykarpatskyi natsionalnyi universytet imeni Vasylia Stefanyka, Ivano-Frankivsk, 2010.

[11] S. S. Bacanov Strukturnaja himija. Fakty i zavisimosti, (Dialog-MGU, Moskva, 2000).

[12] V.V. Svetuhin, S.V. Buljarskij, D.V. Sanchishhin, Pis'ma v ZhTF, 30 (6), 9 (2004).

[13] D.M. Freik, I.V. Horichok, M.V. Shevchuk, L.V. Turovska, Physics and Chemistry of Solid State, 12 (2), 378 (2011).

[14] A. Sakalas, Z. Janushkevichjus, Tochechnye defekty v poluprovodnikovyh soedinenijah (Nauka, Moskva, 1988).

[15] L. A. Sergeeva, NM, 16 (8), 1346 (1980).

[16] Ju. N. Ravich, V. A. Efimova, V. A. Smirnova, Metody issledovanija poluprovodnikov v primenenii k hal'kogenidam svinca PbTe, PbSe, PbS (Nauka, Moskva, 1968). 


\title{
Прокопів В.В. ${ }^{1}$, Горічок I.В. ${ }^{1}$, Семко Т.О. ${ }^{1}$, Дзумедзей Р.О. ${ }^{1}$, Матеїк Г.Д. ${ }^{2}$, Хшановська O.I. ${ }^{1}$
}

\section{Термодинамічний аналіз дефектної підсистеми кристалів плюмбум телуриду з домішкою оксигену}

\author{
${ }^{1}$ Прикарпатського наиіонального університету імені Василя Стефаника, \\ вул. Шевченка, 57, м. Івано-Франківськ, 76018, Україна, E-mail: fcss@ pu.if.иа \\ ${ }^{2}$ Івано-Франківський національний технічний університет нафти і газу, \\ вул. Карпатська, 15, м. Івано-Франківськ, 76000, Украӥна
}

\begin{abstract}
Досліджено електрофізичні властивості (питома електропровідність, коефіцієнт термо-ЕРС, ефект Холла) плюмбум телуриду отриманого пресуванням порошку. При цьому порошок попередньо проходив термічну обробку при $300{ }^{\circ} \mathrm{C}$ на повітрі для насичення його оксигеном. Для інтерпретації отриманих експериментальних даних запропоновано модель дефектної підсистеми легованих оксигеном кристалів плюмбум телуриду.

Ключові слова: плюмбум телурид, легування, пресування, термо-ЕРС.
\end{abstract}

